DE DE GRUYTER

OPEN
Journal of Intercultural Management

Vol. 6, No. 2, April 2014, pp. 19-33

DOI 10.2478/joim-2014-0009

\author{
Aneta Ejsmont \\ University of Social Sciences
}

\title{
Coopetition as a Chance of Increasing The Level of Investments Made by Family Companies in Poland
}

\begin{abstract}
The main problem described by the authoress of the present article is increased investment risk of family companies in Poland by worse economic situation in our country. Authoress' planned aim of the present study is to demonstrate the joint-stock companies listed on the New Connect market who as potential investors must be aware of the risk connected with investing in financial instruments in The Alternative System of Turnover and their investment decisions should be preceded by proper analysis and, if situation requires it, consultation with an investment adviser, what for many micro, small and middle family firms is unfortunately simply too expensive. The condition to increase the level of investments in the researched family companies in Poland is coopetition of that companies with big holding companies or concerns from Poland and with economic entities from other EU countries. In order to do so was made an analysis of the researched enterprises which are joint-stock companies listed on the New Connect market with regard to the level of investments which can influence intensity of cooperation and competition of family firms in Poland with other economic entities.

Key words: family company, joint-stock company, coopetition, cooperation, competition, investments, The European Union

\section{Introduction}

Investing and modernization of processes and products resulting from it as well as increasing the effectiveness of action seem to be, particularly in the situation of global competing, the key to survive of many family companies in Poland. Therefore, the main problem described in this article is increased investment risk of family companies in Poland as a result of worse and worse economic situation in our country. The aim of the authoress of this study is to present the companies listed on the New Connect market which as potential
\end{abstract}


investors must be aware of the risk connected with investing in financial instruments in The Alternative System of Turnover and their investment decisions should be preceded by proper analysis as well as in some cases a consultation with an investment adviser, what unfortunately for many micro, small and middle family firms is simply too expensive.

From the data presented in the report on the condition of small and middle companies in 2011-2012 results that the biggest growth dynamics of total outlays in 2008 in relation to 2003 characterized big companies (190\%), then middle firms (176\%), micro (148\%) and small (132\%). Similarly was presented the dynamics per one enterprise, although in this case in the first place were the smallest companies, next middle (169\%), big (148\%) and small (119\%). This positive tendency started changing in 2009 when these companies noticed first falls in value of outlays in relation to previous year, another reductions in the investment dimension took place in 2010. In 2011 in relation to 2003 microenterprises increased the total outlays by over $260 \%$, and in counting per one enterprise by over $250 \%$ [Tarnawa, Zadura- Lichota 2013, p. 39].

The condition of increasing the level of investments in the researched family companies in Poland is coopetition of these companies with big holding companies or concerns from Poland as well as with economic entities from other EU countries, and this is defined as a phenomenon of cooperation, i.e. joint action of at least two entities which in this way aim at better realization of their targets or achieving a common goal and competition simultaneously [Bengtsson, Kock 2000, p. 420; Cygler 2009, p. 15]. With reference to the above, in this study coopetition will be divided in two basic elements: cooperation and competition.

The authoress to confirm the validity of accepted researching hypothesis tries to assess coopetition of family companies from SME's sector with economic entities from other EU countries as well as with other big firms in Poland. In order to achieve this was made an analysis of the researched enterprises which are joint-stock companies listed on the New Connect market with regard to the level of investments influencing the intensity of both cooperation and competition of family firms in Poland with other economic entities.

\section{Analysis of Polish family companies investment ability in 2003-2011}

According to the Accounting Act, by investments we understand assets which are hold in order to achieve economic benefits arising from the growth of value of these assets, getting from them revenues in the form of interests, dividends (shares in profits) or other advantages also from commercial transaction and in particular financial assets and those properties and intangible and legal values which are not used by an individual, but are used by that individual to achieve those benefits [Wawrzyńczak-Jędryka 2012, p. 554]. However, the 
investment risk means such a situation in which future incidents cannot be foreseen with certainty, but the distribution of probability of those events is known [Czekaj, Dresler 2013, p. 34], what can be a huge difficulty for many family firms operating on domestic and international markets.

Family companies play an important role in the economy of Poland, the European Union and rest of the world. In the EU such companies make about $60 \%$ of all firms. Majority of them are micro and small companies. But there also are middle and big companies. It is estimated that there are about two million family firms in Poland [Manifest. Rodzinna gospodarka, http://firmyrodzinne. $\mathrm{pl} / \mathrm{o}$-ifr/manifest.html].

Starting from 2003 up to 2011 investment activity was run by 17,2\% of enterprises. Total investment outlays of enterprises sector in 2011 amounted to PLN 161,2 bn. what meant growth of about 14\% in relation to 2010 [Tarnawa, Zadura- Lichota 2013, p. 38; Firmy rodzinne na polskim rynku, http://www. bankier.pl/wiadomosc/Firmy-rodzinne-na-polskim-rynku-2197396.html]. The investment outlays of the companies in Poland per one enterprise in 2011 increased by over 2000 PLN in relation to 2010. An average family company increased the investment outlays by over $10 \%$. An average middle family company did the biggest growth of the outlays (growth of outlays of 10\%), then big (growth of over 13,9\%), micro (growth of 9\%) and at the end - small (7\%) [Tarnawa, Zadura-Lichota 2013, p. 38; Firmy rodzinne na polskim rynku, http:// www.bankier.pl/wiadomosc/Firmy-rodzinne-na-polskim-rynku-2197396. html].

From the point of view of particular groups of enterprises according to the size in 2011 the most invested big entities - about 40\% of the total outlays. Second were middle firms, whose outlays were over $19 \%$ of total value. The least share in value of total outlays were small and micro family firms. It is essential that the structure of outlays in the sector of family companies in particular size groups was on the level similar to 2010 [Tarnawa, Zadura- Lichota 2013, p. 38; Firmy rodzinne na polskim rynku, http://www.bankier.pl/wiadomosc/Firmyrodzinne-na-polskim-rynku-2197396.html].

Taking into consideration an investment activity of family companies in Poland in 2003-2011 we could observe three characteristic sub-periods. First from 2003 to 2008, second - from 2008 to 2010 and third - from 2010 to 2011, which are presented in the graph below. 
Chart 1. Dynamics of total investment outlays in Poland in groups of family companies according to size in 2003-2011 (2003=100\%).

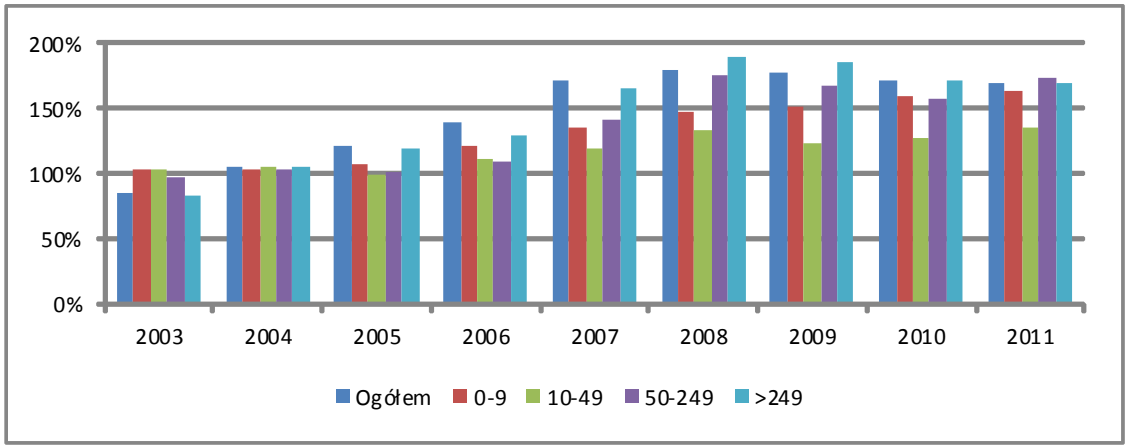

Source: [Own study based on Tarnawa, Zadura-Lichota 2013, p. 38; Firmy rodzinne na polskim rynku, http://www.bankier.pl/wiadomosc/Firmy-rodzinne-na-polskim-rynku-2197396.html].

As it was mentioned in the introduction, in 2003-2008 in all groups of companies dynamics of investment outlays in relation to 2003 increased significantly - both total and per one enterprise. Similar was the dynamics per one enterprise - although in this case on the first place were the smallest companies, next the middle (169\%), big (148\%) and small (119\%) what is presented in the graph below.

Chart 2. Dynamics of investment outlays per one enterprise in Poland in groups of family companies according to size in 2003-2011 (2003=100\%).

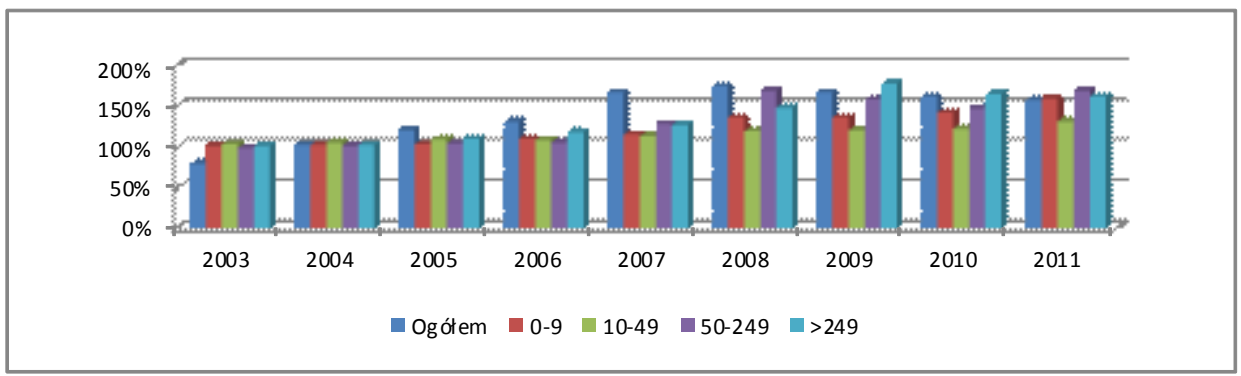

Source: [Own study based on Tarnawa, Zadura-Lichota 2013, p. 38; Firmy rodzinne na polskim rynku, http://www.bankier.pl/wiadomosc/Firmy-rodzinne-na-polskim-rynku-2197396.html].

On the basis of the above chart it may be unambiguously stated that the dynamics of investment outlays per one family enterprise shaped similarly as in the case of total investment outlays. However, smaller companies showed greater investment ability, in contrast to big concerns or holding companies, 
risking more than big economic entities. It resulted from the fact that the main source of financing investments in small and middle family companies in Poland were and still are own resources but on the second place are funds from domestic and foreign credits and loans what is quite risky, especially during unstable economic situation in our country. However, comforting is fact that small and middle firms have less to lose, whereas big companies - much more [Beersma 2002, p. 5].

Meanwhile, every economic decision concerning both current activity of a company and its investment plans is based on a forecast of future conditions of an activity, and therefore on predictions which are always burdened with some dose of uncertainty. Because we cannot establish in an absolutely sure way how particular factors making basis for present decision will shape in a week, month or year [Ejsmont 2013, p. 42].

\section{Influence of cooperation on the investment ability of family companies in Poland}

Managers of family companies during realization of investments by choosing the best investment projects from all proposed should be guided by specific criteria [Bakos 2011, p. 4]. If they have clear rules about making investment decisions, then they can formalize whole company's investment process and define which assumptions and which data can characterize that project [Greif 2012, p. 7]. Therefore, in process of making investment decisions the superior role should play cooperation of micro, small and middle family companies with bigger economic entities realizing investments on domestic and EU market.

Researching the influence of cooperation on the investment ability of family companies in Poland from among twelve chosen small and middle jointstock companies conducting their economic activity in different branches, which whereas are listed on the New Connect market, the authoress analysed ten family firms which are characterized by starting cooperation with other economic entities. An example of one from the ten joint-stock companies which cooperate with other firms on a wide scale is a family company "Alda" Inc. with the registered office in Ząbkowice Śląskie. This company produces household commodities. Unfortunately, as the majority of family firms in Poland, this enterprise is also exposed to many risk factors, including the following [Dokument Informacyjny Alda... 2011, p. 7-10]:

- risk factors connected with strategic aims, realised by the board of directors of the joint- stock;

- risk factors connected with leaving of crucial members of the board of directors and difficulties connected with gaining new qualified managing staff; 
- risk factors connected with subordinating the company from economic entities connected with it in terms of capital or personally;

- risk factors connected with the change of exchange rates (import transactions are accounted for in the foreign currency mainly in USD);

- risk factors connected with fluctuations of interest rates;

- risk factors connected with competition;

- risk factors connected with the macroeconomic situation;

- risk factors connected with fluctuations of shares quotations within the Alternative System of Turnover.

The above risk factors are factors of investment risk which have indirect or direct influence on decreasing the level of investments realized by companies in Poland. Meanwhile, making investment decisions by the majority of family firms such as the joint-stock company "Alda" Inc. is a component of many factors among which the amount of interest rates and required protections make essential elements of survival of the researched economic entity on the market.

The main aim of the joint-stock company "Alda" Inc. is gaining new cooperative contractors. Similar aims realize remaining family companies analised by the authoress. The analysed companies mainly start cooperation with contractors on domestic market and in a smaller degree with foreign ones. Whereas investments realized with dynamic development of the researched economic entities in mind are mainly on domestic market. With reference to the above, on the basis of financial balances made by the researched companies, this article analyses the amounts of short- and long-term investments made by selected economic entities in 2010-2011. The data are presented in the table below (compare Table 1).

Table 1. The short-term and long-term investments made by selected joint-stock companies listed on the New Connect in 2010-2011 (data in thousands of PLN)

\begin{tabular}{|l|l|l|}
\hline $\begin{array}{l}\text { Name of the joint-stock } \\
\text { company }\end{array}$ & 2010 & 2011 \\
\hline ALDA INC. & 26839,85 & 61444,89 \\
\hline BIOGENED INC. & 145778,06 & 249011,77 \\
\hline BIOMED INC. & 17621,80 & 17461,36 \\
\hline MABION INC. & (state on 2010.03.31) 4148,07 & 0 \\
\hline INDEXMEDICA INC. & 630065,94 & 697113,11 \\
\hline REVITUM INC. & 15238,56 & 105713,92 \\
\hline SWISSMED INC. & $($ state on 2010.09 .30$)$ 1978,44 & 0 \\
\hline STEM CELLS SPIN INC. & 1527081,96 & $($ state on 2011.06 .30$)$ \\
& & 1175771,74 \\
\hline SELVITA INC. & 329398,47 & 0 \\
\hline
\end{tabular}




\begin{tabular}{|l|l|l|}
\hline TELEMEDYCYNA INC. & $\begin{array}{l}\text { (state on 2010.06.30) } \\
279323,69\end{array}$ & 0 \\
\hline
\end{tabular}

Source: [Dokument Informacyjny Alda... 2011, p. 76-115; Dokument Informacyjny Biogened... 2011, p. 103-129; Dokument Informacyjny Biomed... 2011, p. 104-137; Dokument Informacyjny Mabion... 2010, p. 52-100; Dokument Informacyjny Indexmedica... 2012, p. 67-85; Dokument Informacyjny Revitum... 2012, p. 65-89; Dokument Informacyjny Swissmed Prywatny Serwis Medyczny... 2011, p. 47-104; Dokument Informacyjny Stem Cells Spin... 2011, p. 70-119; Dokument Informacyjny Selvita... 2011, p. 76-121; Dokument Informacyjny Telemedycyna... 2010, p. 81-134].

On the basis of the above data from Table 1 the authoress made T-test for dependent samples. In the conducted test the authoress compares means with reference to the amount of the short- and long-term investments from two years (2010-2011). Researching the influence of cooperation on the ability of investments realized by selected family firms in Poland we can formulate the following question: "Does cooperation influence the increase of investment ability of family companies in Poland?". This question is at the same time the searching problem of the present article. With reference to the above, we can assume that cooperation of the analysed joint-stock companies in the present dimension influence the increase of their investment abilities, what is also the hypothesis. The zero hypothesis is opposite of the previously accepted assumption. The data are presented in the table below (compare Table 2).

Table 2. T- test for dependent samples (marked differences are significant at $\mathrm{p}<0,05)$

\begin{tabular}{|l|l|l|l|l|l|l|l|l|l|l|}
\hline $\begin{array}{l}\text { Vari- } \\
\text { able }\end{array}$ & Mean & $\begin{array}{l}\text { Std. Dv. } \\
\text { (Standard } \\
\text { deviation) }\end{array}$ & N & Difference & $\begin{array}{l}\text { Std. Dv. } \\
\text { Differ- } \\
\text { ence }\end{array}$ & t & df & p & $\begin{array}{l}\text { confidence } \\
-95,000 \%\end{array}$ & $\begin{array}{l}\text { confi- } \\
\text { dence } \\
+95,000 \%\end{array}$ \\
\hline 2010 & 297747,5 & 477433,8 & & & & & & & & \\
\hline 2010 & 297747,5 & 477433,8 & 10 & 0,0 & 0,0 & 0,00000 & 9 & 1,000000 & 0 & 0,00 \\
\hline 2010 & 297747,5 & 477433,8 & & & & & & & & \\
\hline 2011 & 230651,7 & 396325,7 & 10 & 67095,8 & 179345,2 & 1,18306 & 9 & 0,267095 & -195392 & 61200,05 \\
\hline 2011 & 230651,7 & 396325,7 & & & & & & & & \\
\hline 2010 & 297747,5 & 477433,8 & 10 & $-67095,8$ & 179345,2 & $-1,18306$ & 9 & 0,267095 & -195392 & 61200,05 \\
\hline 2011 & 230651,7 & 396325,7 & & & & & & & & \\
\hline 2011 & 230651,7 & 396325,7 & 10 & 0,0 & 0,0 & 0,00000 & 9 & 1,000000 & 0 & 0,00 \\
\hline
\end{tabular}

Source: [Own study on base Dokument Informacyjny Alda... 2011, p. 76-115; Dokument Informacyjny Biogened... 2011, p. 103-129; Dokument Informacyjny Biomed... 2011, p. 104137; Dokument Informacyjny Mabion... 2010, p. 52-100; Dokument Informacyjny Indexmedica... 2012, p. 67-85; Dokument Informacyjny Revitum... 2012, p. 65-89; Dokument Informacyjny Swissmed Prywatny Serwis Medyczny... 2011, p. 47-104; Dokument Informacyjny Stem Cells Spin... 2011, p. 70-119; Dokument Informacyjny Selvita... 2011, p. 76-121; Dokument Informacyjny Telemedycyna... 2010, p. 81-134]. 
The above table contains data concerning the dependent variables which are years 2010-2011, means, standard deviations counted for ten chosen companies listed on the New Connect market, differences between counted standard deviations, the critical value in T-test, degrees of liberty for $\mathrm{n}-1$ that is joint numerical force of samples, divisions of confidence for that test which are situated in division $(-95 \%,+95 \%)$ and what is the most important - the gravity of the test (p-value). The above values in the expressive way are reflected the following chart (compare Chart 3).

Chart 3. T-test for dependent samples reflecting influence of cooperation on the short-term and long-term investments of the chosen joint-stock companies listed on the New Connect in 2010-2011.

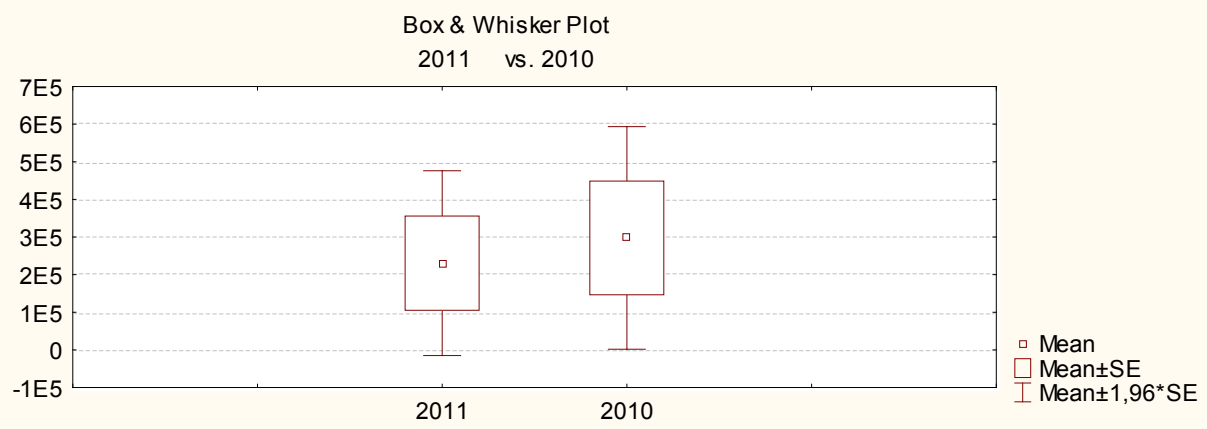

Source: [Own study on base Dokument Informacyjny Alda... 2011, p. 76-115; Dokument Informacyjny Biogened... 2011, p. 103-129; Dokument Informacyjny Biomed... 2011, p. $104-$ 137; Dokument Informacyjny Mabion... 2010, p. 52-100; Dokument Informacyjny Indexmedica... 2012, p. 67-85; Dokument Informacyjny Revitum... 2012, p. 65-89; Dokument Informacyjny Swissmed Prywatny Serwis Medyczny... 2011, p. 47-104; Dokument Informacyjny Stem Cells Stem... 2011, p. 70-119; Dokument Informacyjny Selvita... 2011, p. 76-121; Dokument Informacyjny Telemedycyna... 2010, p. 81-34].

In the student $\mathrm{T}$-test for dependent samples the most important measure is exactly "p", that is the gravity of the test. If the researched gravity is smaller than 0,05 then we will reject the zero hypothesis which assumes that cooperation of the researched family companies in Poland in present dimension does not influence the increase of their investment ability. Presented data show the fact that in the analysed case we have $p>0,05$. Therefore, we could not reject the accepted zero hypothesis.

Summing up the above considerations, it should be stated that $p>0,05$ means insufficient influence of cooperation of the researched family firms in Poland in the present dimension on the increase of their investment ability. As the authoress has emphasized before, the researched companies start cooperation 
mainly with contractors on domestic market and in a smaller degree with foreign ones. Whereas investments are realized with the idea of a dynamic development of the researched economic entities but mainly on the domestic market. The results of the above test indicate that family companies in Poland should be more opened to cooperation with other, even larger companies from EU countries.

\section{The influence of competition on the investment ability of family companies in Poland}

Management of the joint-stock companies listed on the New Connect market, takinginto account theirvariety of organizationalstructures, acceptedstrategies and used economic, balance and tax policies, is unusually difficult [Ejsmont 2013, p. 174]. Therefore, aiming of family companies and their competitors to achieve competing dominance is one of the forces which contributed to the development of competition and will also motivate those enterprises to much more intensive actions in the scope of competing processes. The fact if a company is more or less competing has a huge influence in its investment ability, which, whereas, strongly depends on factors of the investment risk [Boukouras 2008 , p. 11]. An example of a family company whose level of competitiveness depends on the analyzed risk factors, is a firm "Revitum" Inc. from Warsaw. The basic activities of this company are body diagnostic tests and the sale of diet supplements. The economic situation in Poland has significant influence on the financial results achieved by the company. Possible decreasing of investment outlays can unfavourable influence the financial situation of the researched economic entity. In the case when economic situation in Poland with regard to both external and internal factors is getting worse, the results and financial situation of the company may also be worse, what can have a negative influence on the results made by that company. In order to limit that risk the board of directors in the company monitors economic situation in Poland all the time and adapts the strategy of the company to appearing changes in advance.

The company "Revitum" Inc. perceives its main dominance over the competition in a "network" character of business. Branch offices network allows increased recognizability of trademark among clients and builds trust of potential new clients who go on a first visit. Such approach to business is at the moment the only one on the biomedicine market and gives possibilities to considerably decrease costs which are assigned to marketing activities and expansion on the Polish market. The following table shows data concerning the amount of the short- and long-term investments in 2010-2011 noticed by companies which similarly as in the case of "Revitum" Inc. run their expansion mainly on the domestic market and in a lower degree on international markets. In following table presents data from joint-stock companies listed on the New 
Connect market which cooperate and compete with other economic entities, except "Synektik" Inc. and "GC Investment" Inc. which in a larger degree are oriented to competition with other companies (compare Table 3).

Table 3. The short-term and long-term investments made by selected jointstock family companies listed on the New Connect market in 2010-2011 (data in thousands of PLN)

\begin{tabular}{|l|l|l|}
\hline Company & 2010 & 2011 \\
\hline BIOMED INC. & 17621,80 & 17461,36 \\
\hline SYNEKTIK INC. & 911346,94 & 0 \\
\hline INDEXMEDICA INC. & 630065,94 & 697113,11 \\
\hline REVITUM INC. & 15238,56 & 105713,11 \\
\hline SWISSMED INC. & (state on 30.09 .2010 r.) 1978,44 & 0 \\
\hline GC INVESTMENT INC. & 31382256,52 & 0 \\
\hline TELEMEDYCYNA INC. & $\begin{array}{l}\text { (state on } 30.06 .2010 \\
\text { 279323,69 }\end{array}$ & 0 \\
\hline
\end{tabular}

Source: [Dokument Informacyjny Biomed... 2011, p. 104-137; Dokument Informacyjny Synektik... 2011, p. 107-120; Dokument Informacyjny Indexmedica... 2012, p. 67-85; Dokument Informacyjny Revitum... 2012, p. 65-89; Dokument Informacyjny Swissmed Prywatny Serwis Medyczny... 2011, p. 47-104; Dokument Informacyjny GC Investment... 2011, p. 98-172; Dokument Informacyjny Telemedycyna... 2010, p. 81-134].

On the basis of the above data presented in Table 3 , similarly as in the case of researching the influence of cooperation on the investment ability of selected family companies listed on the New Connect market, the authoress made Ttest for dependent samples. In the conducted test the authoress compares means referred to the amount of the short-term and long-term investments from two years (2010-2011). Researching the influence of competition on the ability of investments realized by the chosen family firms in Poland we can formulate the following question: "Does competition influence the increase of the investment ability of family companies in Poland?" This question is at the same time the second component of the searching problem in this article. With reference to the above, we can assume that competition of the analyzed joint-stock companies in the present dimension influences the increase of their investment ability, what is the hypothesis. The zero hypothesis whereas is the opposite of the previously accepted assumption. The data are presented in the table below (compare Table 4). 
Table 4. T-test for dependent samples (marked differences are significant at $\mathrm{p}<0,05)$

\begin{tabular}{|l|l|l|l|l|l|l|l|l|l|l|}
\hline $\begin{array}{l}\text { Vari- } \\
\text { able }\end{array}$ & Mean & $\begin{array}{l}\text { Std. Dv. } \\
\text { (Stan- } \\
\text { dard } \\
\text { devia- } \\
\text { tion) }\end{array}$ & N & $\begin{array}{l}\text { Differ- } \\
\text { ence }\end{array}$ & $\begin{array}{l}\text { Std. Dv. } \\
\text { Differ- } \\
\text { ence }\end{array}$ & t & df & $\mathrm{p}$ & $\begin{array}{l}\text { confi- } \\
\text { dence } \\
-95,000 \%\end{array}$ & $\begin{array}{l}\text { confi- } \\
\text { dence } \\
+95,000 \%\end{array}$ \\
\hline 2010 & 4748262 & 11749682 & & & & & & & & \\
\hline 2010 & 4748262 & 11749682 & 7 & 0 & 0 & 0,00000 & 6 & 1,000000 & 0 & 0 \\
\hline 2010 & 4748262 & 11749682 & & & & & & & & \\
\hline 2011 & 117184 & 258625 & 7 & 4631078 & 11801406 & 1,03824 & 6 & 0,339177 & -15545558 & 6283403 \\
\hline 2011 & 117184 & 258625 & & & & & & & & \\
\hline 2010 & 4748262 & 11749682 & 7 & -4631078 & 11801406 & $-1,03824$ & 6 & 0,339177 & -15545558 & 6283403 \\
\hline 2011 & 117184 & 258625 & & & & & & & & \\
\hline 2011 & 117184 & 258625 & 7 & 0 & 0 & 0,00000 & 6 & 1,000000 & 0 & 0 \\
\hline
\end{tabular}

Source: [Own study on base Dokument Informacyjny Biomed... 2011, p. 104-137; Dokument Informacyjny Synektik... 2011, p. 107-120; Dokument Informacyjny Indexmedica... 2012, p. 67-85; Dokument Informacyjny Revitum... 2012, p. 65-89; Dokument Informacyjny Swissmed Prywatny Serwis Medyczny... 2011, p. 47-104; Dokument Informacyjny GC Investment... 2011, p. 98-172; Dokument Informacyjny Telemedycyna... 2010, p. 81-134].

Similarly as in the case of researching the influence of cooperation on the investment ability of the researched companies, also here the gravity of the test ( $p$-value) is of essential significance. The above values are reflected in the expressive way in the following chart (compare Chart 4).

Chart 4. T- test for dependent samples reflecting influence of competition on the short-term and long-term investments of selected joint-stock companies listed on the New Connect in 2010-2011

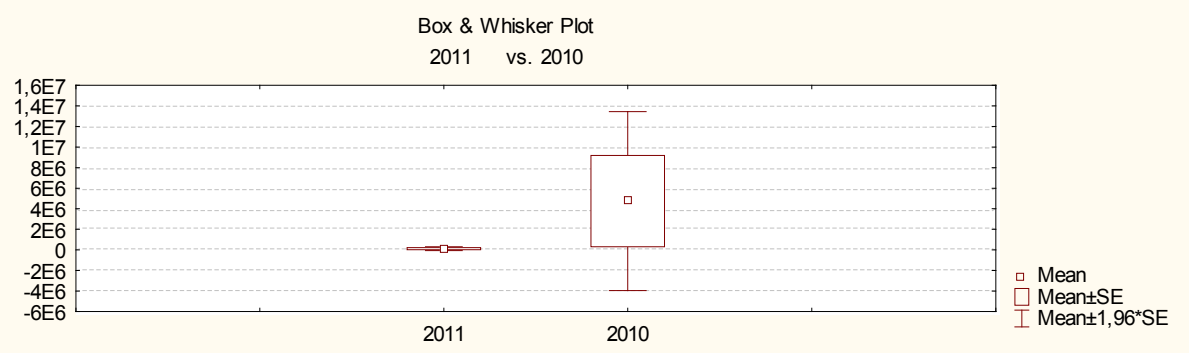

Source: [Own study on base Dokument Informacyjny Biomed... 2011, p. 104-137; Dokument Informacyjny Synektik... 2011, p. 107-120; Dokument Informacyjny Indexmedica... 2012, p. 67-85; Dokument Informacyjny Revitum... 2012, p. 65-89; Dokument Informacyjny Swissmed Prywatny Serwis Medyczny... 2011, p. 47-104; Dokument Informacyjny GC Investment... 2011, p. 98-172; Dokument Informacyjny Telemedycyna... 2010, p. 81-134]. 
As the authoresshas mentioned previously, in the student $\mathrm{T}$ - test for dependent samples the most important measure is exactly "p", that is the gravity of the test. If the researched gravity is smaller than 0,05 , then we will reject the zero hypothesis which assumes that competition of the researched family companies in Poland in the present dimension does not influence the increase of their investment ability. Presented data indicate the fact that in the analysed case we have $\mathrm{p}>0,05$. Therefore, we could not reject the accepted zero hypothesis.

Summing up the above considerations, it should be stated that $\mathrm{p}>0,05$ means insufficient influence of competition of the researched family firms in Poland in the present dimension on the increase of their investment ability. As the authoress emphasized before, the researched companies aim at implementing their development strategy mainly on domestic market without trying to run the economic expansion on a larger scale beyond the borders of our country. Results of the above test indicate that family companies in Poland in a greater degree should sharpen competition trying to compete not only with firms on domestic market but also with foreign economic entities and not necessarily with micro, small or middle enterprises.

\section{Conclusion}

To function effectively family companies in Poland should have proper capital. Planning the purchase of new equipment, change of the registered office, increase of the activity scale, development of new products, they all can increase the demand of a company on capital [Hovenkamp 2013, p. 12; Simkovic 2013, p. 9].

With reference to the above, the authoress in the present article researched the influence of cooperation and competition treated generally as coopetition on the level of investments and precisely on the investment ability of family companies in Poland. Therefore, the authoress conducted T-test for dependent samples. The authoress made a division of phenomenon which is coopetition, on cooperation and competition. Researching the influence of cooperation on the investment ability of family companies the authoress analysed ten different companies from different branches listed on the New Connect market. Whereas when researching the influence of competition on the investment ability of family companies authoress analysed seven companies from which five were also analysed with regard to the influence of cooperation on the investment ability of family firms in Poland.

In both cases we could observe too weak engagement of the researched firms in cooperation and competition on the foreign and EU markets. The analysed companies in a larger degree started cooperation running the competing strategy mainly on domestic market. The authoress assumed that 
both cooperation and competition of the analysed joint-stock companies generally influence the increase of their investment ability what was also the main searching hypothesis. Whereas the zero hypothesis is opposite to what authoress assumed earlier.

In T-test for dependent samples the most important measure is the so-called "p", i.e. the gravity of the test. If the researched gravity is smaller than 0,05 , then we will reject the zero hypothesis which assumes that both cooperation and competition of the researched family companies in Poland in the present dimension does not influence the increase of their investment ability. Presented data indicated the fact that in the analysed case we have $p>0,05$. With reference to that, the zero hypothesis was confirmed.

The investment processes should be realized using the short- term and longterm investments. Increasing or decreasing the amount of the investment outlays depends on the so-called "factors of the investment risk", which on the other hand are influenced by the economic situation in Poland. Decreasing the amount of the investment outlays influences unfavorably financial situation of the researched family firms. Therefore, boards of directors in the researched joint-stock companies monitor economic situation in Poland and adapt in advance the strategies of companies to appearing changes.

As the authoress indicated in the conducted student T-test, the researched companies start cooperation trying at the same time to compete with other economic entities mainly on domestic market, and in lower degree - with foreign contractors.

Not the best economic situation in our country causing increase of investment risk contributing to the decrease of the level of investments realized by family companies in Poland should much more encourage family firms to coopetition not only on domestic market but much more on international markets, cooperating and simultaneously competing with big concerns or holding companies.

\section{Bibliography}

Bakos Y., Cooperation Without Enforcement? A Comparative Analysis of Litigation and Online Reputation as Quality Assurance Mechanisms (2011), http://papers.ssrn.com/ sol3/papers.cfm?abstract_id=393041, access: 15 February 2014.

Beersma B., Cooperation, Competition, and Team Performance: Towards a Contingency Approach (2002), http://papers.ssrn.com/sol3/papers.cfm?abstract_id=325401, access: 15 February 2014.

Boukouras A., Koufopoulos K., Frictions to Political Competition and Financial Openness (2008), http://papers.ssrn.com/sol3/papers.cfm?abstract_id=1217093, access: 15 February 2014. 
Bengtsson M., Kock S. (2000), „Coopetition” in Business Network- Cooperate and Compete Simultaneously, „Industrial Marketing Management”, vol. 29.

Cygler J. (2009), Kooperencja przedsiębiorstw. Czynniki sektorowe $i$ korporacyjne, Wydawnictwo Szkoły Głównej Handlowej w Warszawie, Warszawa.

Czekaj J, Dresler Z. (2013), Zarządzanie finansami przedsiębiorstw. Podstawy teorii, PWN, Warszawa.

Dokument Informacyjny Alda Spółka Akcyjna (2011), Warszawa.

Dokument Informacyjny Biogened Spótka Akcyjna (2011), Warszawa.

Dokument Informacyjny „Biomed- Lublin” Wytwórnia Surowiec i Szczepionek Spótka Akcyjna (2011), Warszawa.

Dokument Informacyjny GC Investment Spółka Akcyjna (2011), Warszawa.

Dokument Informacyjny Indexmedica Spótka Akcyjna (2012), Warszawa.

Dokument Informacyjny Mabion Spótka Akcyjna (2010), Warszawa.

Dokument Informacyjny Revitum Spółka Akcyjna (2012), Warszawa.

Dokument Informacyjny Selvita Spółka Akcyjna (2011), Warszawa.

Dokument Informacyjny Stem Cells Spin Spółka Akcyjna (2011), Warszawa.

Dokument Informacyjny Swissmed Prywatny Serwis Medyczny Spótka Akcyjna (2011), Warszawa.

Dokument Informacyjny Synektik Spółka Akcyjna (2011), Warszawa.

Dokument Informacyjny Telemedycyna Polska Spótka Akcyjna (2010), Warszawa.

Ejsmont A. (2013), Modele wzrostu przedsiębiorstwa a sprawność procesów kooperacyjnych sektora MSP w Polsce (studium przypadku), in: A. Olak, E. Szymańska, A. Trzyna (red.), Zmiany $w$ regionie $w$ warunkach globalizacji, STOWARZYSZENIE Nauka, Edukacja, Rozwój, Ostrowiec Świętokrzyski.

Ejsmont A. (2013), Wpływ procesów kooperencyjnych na wyniki finansowe firm rodzinnych w Polsce (studium przypadku), in: A. Marjański, B. Piasecki (red.), Firmy rodzinne wyzwania globalne i lokalne, Tom XIV, Zeszyt 6, Część II, Wydawnictwo Społecznej Akademii Nauk, Łódź.

Firmy rodzinne na polskim rynku, http://www.bankier.pl/wiadomosc/Firmy-rodzinnena-polskim-rynku-2197396.html, access: 6 February 2014.

Greif A., Tabellini G., The Clan and the City: Sustaining Cooperation in China and Europe (2012), http://papers.ssrn.com/sol3/papers.cfm?abstract_id=2101460, access: 15 February 2014.

Hovenkamp H., Innovation And Competition Policy, Chapter 4 (2d): Competition Policy And The Patent System (2013), http://papers.ssrn.com/sol3/papers.cfm?abstract_ id=1938310, access: 15 February 2014.

Manifest. Rodzinna gospodarka, http://firmyrodzinne.pl/o-ifr/manifest.html, access: 6 lutego 2014.

Simkovic M., Competition and Crisis in Mortgage Securitization (2013), http://papers. ssrn.com/sol3/papers.cfm?abstract_id=1924831, access: 6 February 2014. 
Tarnawa A., Zadura-Lichota P. (red.) (2013), Raport o stanie sektora małych i średnich przedsiębiorstw w latach 2011-2012, Polska Agencja Rozwoju Przedsiębiorczości, Warszawa.

Wawrzyńczak-Jędryka B. (red.) (2012), Meritum. Rachunkowość i sprawozdawczość finansowa, Wydawnictwo Wolters Kluwer Polska Spółka z o.o., Warszawa. 